\title{
Use of Flame Atomic Absorption Spectroscopy and Multivariate Analysis for the Determination of Trace Elements in Human Scalp
}

\author{
Sayo O. Fakayode*, Sri Lanka Owen, David A. Pollard, Mamudu Yakubu \\ Department of Chemistry, Winston-Salem State University, Winston-Salem, USA \\ Email: fakayodesa@wssu.edu
}

Received June 7, 2013; revised July 1, 2013; accepted July 11, 2013

Copyright (C) 2013 Sayo O. Fakayode et al. This is an open access article distributed under the Creative Commons Attribution License, which permits unrestricted use, distribution, and reproduction in any medium, provided the original work is properly cited.

\begin{abstract}
The analysis of trace elements in human hair for use as biomarkers continues to generate considerable interest in environmental and bioanalytical studies, medical diagnostics, and forensic science. This study investigated the concentrations of essential and toxic elements $(\mathrm{Fe}, \mathrm{Mg}, \mathrm{Ca}, \mathrm{Cu}, \mathrm{Zn}, \mathrm{Cr}, \mathrm{Cd}$, and $\mathrm{Pb}$ ) using flame atomic absorption spectroscopy (FAAS) in human scalp hair obtained from subjects living in Forsyth County, North Carolina, USA. The influence of age, sex, race, and smoking habits on the levels of trace elements in the hair samples were also investigated. Additionally, analyses were subjected to a statistical, regression, and principal component analysis to evaluate inter-elemental association and possible pattern recognition in hair samples. Furthermore, $\mathrm{Ca} / \mathrm{Mg}$ and $\mathrm{Zn} / \mathrm{Cu}$ ratios, which are often used to evaluate the degree of $\mathrm{Ca}$ and $\mathrm{Cu}$ utilization in humans and as markers for various health related issues including, atherosclerosis, hypertension, insulin sensitivity, and pancreatic cancer, were calculated. The overall mean concentrations of Fe $(25 \mu \mathrm{g} / \mathrm{g}), \mathrm{Ca}(710 \mu \mathrm{g} / \mathrm{g}), \mathrm{Mg}(120 \mu \mathrm{g} / \mathrm{g}), \mathrm{Zn}(190 \mu \mathrm{g} / \mathrm{g}), \mathrm{Cu}(12 \mu \mathrm{g} / \mathrm{g})$, and $\mathrm{Cr}(0.20 \mu \mathrm{g} / \mathrm{g})$ were found in hair samples. The trace element concentrations varied widely in hair samples as demonstrated by large range of concentrations obtained for each element. However, levels of $\mathrm{Cd}$ and $\mathrm{Pb}$ elements of $<0.030 \mu \mathrm{g} / \mathrm{g}$ were detected in hair sample. In general, the levels of the trace elements in hair samples were poorly correlated. However, significant correlations were found between $\mathrm{Ca}$ and $\mathrm{Mg}(r=0.840, p=0.05)$. The levels of $\mathrm{Fe}, \mathrm{Ca}, \mathrm{Mg}, \mathrm{Zn}, \mathrm{Cu}$, and $\mathrm{Cr}$ in hair samples and the calculated $\mathrm{Ca} / \mathrm{Mg}$ and $\mathrm{Zn} / \mathrm{Cu}$ ratios were found to be largely correlated with age, race, sex, and smoking habits.
\end{abstract}

Keywords: Human Scalp Hair; Biomonitoring; Trace Element Concentration; Flame Atomic Absorption Spectroscopy; Regression and Principal Component Analysis; Inter-Element Association

\section{Introduction}

Trace elements, including $\mathrm{Fe}, \mathrm{Ca}, \mathrm{Mg}, \mathrm{Zn}$, and $\mathrm{Cu}$, play critical roles in proper human body development and metabolic activity [1-3]. For example, $\mathrm{Fe}$ is required in the diet for proper functioning of the liver and hemoglobin, a protein in humans primarily responsible for the transportation and distribution of oxygen from the lungs to various human organs [3]. Iron is also a critical component of myoglobin, an oxygen storing heme protein residing in the cell and is responsible for the color of meat [4-7]. Iron deficiency may result in insomnia, stunted growth, decreased immune function and inhibition of hemoglobin synthesis, particularly in women and children, resulting in anemia $[8,9]$. Calcium and magnesium are necessary for effective teeth and bone structure development, fa-

${ }^{*}$ Corresponding author. cilitating transmission of nerves impulses, carbohydrate and protein metabolism, activation of various enzymatic reactions, and enhancement of the absorption of phosphorus and vitamins [3]. Zinc and copper promote normal body metabolism, are critical in normal genetic expression, and are essential co-enzymes, catalyzing various enzymatic reactions $[1,10]$. These trace elements are required at certain concentrations which can be primarily obtained from sufficiently balanced diet and food supplements.

In contrast, heavy metals such as $\mathrm{Pb}$ and $\mathrm{Cd}$ are non essential elements and their presence in the human body can be harmful, with serious health consequences. For instance, health hazards, including reduction of child intelligence quotients, hypertension, depression, mental disorders, cancer diseases, and deoxyribonucleic acid damage 
have been associated with heavy metals at high concentrations [11-15]. Humans are often exposed to heavy metals through various routes, including the consumption of heavy metal contaminated foods or water, occupational exposure in working environments, lead paints, contaminated toys, industrial activity, vehicular emissions, and environmental exposure [16-30]. The critical role of essential elements in normal metabolic activity and the potential negative health consequences of toxic heavy metals necessitate the need for routine biomonitoring of the levels of trace metals elements.

Toward these efforts, various studies have utilized a wide range of human specimens including, human serum, blood, tissues, urine, and saliva as biomarkers for effective biomonitoring of trace element concentrations [3135]. However, these biomarkers have some major drawbacks including, sample susceptibility to contamination, sample decomposition, and instability. Additionally, some human specimens may involve invasive sample collection. Human scalp hair has lately become more preferable to the analysis of traditional human specimens because many trace elements are more concentrated with longer residence times in hair compared to other human specimens. Besides, hair samples are easy to collect, noninvasive, easy to store, and relatively inexpensive. Thus, human hair samples have been effectively used as biomarkers for the determination of trace element concentrations in environmental and bioanalytical studies, clinical and medical diagnosis, occupational health, recreational and therapeutic use, and forensic science [36-56].

We hypothesized that the combined use of analytical spectroscopy, multivariate analysis, statistics, and human scalp hair can be utilized to map the level of essential and potentially toxic trace elements in human subjects. We also hypothesized that race would possibly influence the level of trace elements in the scalp hair of human subjects. Consequently, this study reports for the first time, a comprehensive and combined use of analytical spectroscopy, statistics, multivariate analysis, and human scalp hair as a biomarker for assessing trace element (Fe, $\mathrm{Mg}$, $\mathrm{Ca}, \mathrm{Cd}, \mathrm{Pb}, \mathrm{Cu}, \mathrm{Zn}$, and $\mathrm{Cr}$ ) concentrations in human subjects. The study also reports for the first time, the influence of race on the levels of trace element concentrations and the use of multivariate analysis for trace element pattern recognition in scalp hair of human subjects. Furthermore, the study reports for the first time the influence of race, age, race, sex, on the $\mathrm{Ca} / \mathrm{Mg}$ and $\mathrm{Zn} / \mathrm{Cu}$ ratios (which are often used to evaluate the degree of $\mathrm{Ca}$ and $\mathrm{Cu}$ utilization in human and markers for various health related issues including, atherosclerosis, hypertension, insulin sensitivity, and pancreatic cancer) in the scalp hair of human subjects.

\section{Materials and Methods}

\subsection{Sample Collection and Sample Preparation}

Human scalp hair samples were collected in three cities (Winston-Salem, Clemmons, and Kernersville) in Forsyth County, North Carolina, USA. Forsyth County is 409.60 square miles in area, with a population of 350,670 [57]. Females and males account for $52 \%$ and $48 \%$, respectively of the population. In addition, people under 18 years of age account for $24.6 \%$ of the sample population while those older than 18 years are make-up of $73.4 \%$ of the population in Forsyth County. The demographic racial composition of Forsyth County consists of Caucasians (majority 62.3\%) and non-Caucasians (minority, 37.7\%). Non-Caucasians were made up of African Americans, 26\%; Hispanics, 11.9\%; and Asians, 1.9\%. Scalp hair samples were collected from 125 participants using stainless steel scissors during regular haircut periods at various barber shops and beauty salons over a period of three weeks in June 2011. The sample population consists of 60 males and 65 females aged between 5 and 70 years old. In addition, the hair samples were collected from different races and demographics consisting of Caucasian ( $n$ $=87)$ and non-Caucasians $(n=38)$. Non-Caucasians were made up of African Americans, Hispanics, and Asians. Only eighteen of the people from whom hair samples were collected declared themselves as tobacco product smokers while 107 identified themselves as nonsmokers.

The collected hair samples were immediately placed in cleaned polyethylene plastic bags, properly labeled, and transported to a dust free laboratory, where the samples were sequentially washed with acetone and ethanol, and thoroughly rinsed with deionized water to remove pharmaceutical products, particulates, and other exogenous materials. The washed hair samples were subsequently dried in an oven at $90^{\circ} \mathrm{C}$ for approximately 20 minutes and stored in pre-nitric acid washed Teflon sample containers. Approximately $1.0 \mathrm{~g}$ of dried hair sample from each participant was accurately weighed and digested with $15 \mathrm{~mL} \mathrm{HNO}_{3}$ (trace metal grade, purity, 99.999\%) in a digestion flask. Hair sample digestions were initiated at relatively low temperatures to prevent a violent reaction until all the hair samples were fully dissolved in the nitric acid. The temperature was then subsequently increased until the solution turned pale yellow to ensure complete sample digestion. The nitric acid digested hair samples were filtered into a $25 \mathrm{~mL}$ volumetric flask using a Whatman filter paper (ashless) and diluted to the mark with deionized water.

\subsection{Calibration Curve, Trace Element Analysis, Method Validation, and Quality Assurance}

Working range standard solutions used to construct cali- 
bration curves for each element were prepared by serial dilution of $1000 \mathrm{ppm}$ standard stock solutions of each element purchased from Fisher Scientific. The calibration curve for each element was constructed by plotting the absorbance obtained from FAAS analysis of the standard solution versus the element concentration. The nitric acid digested hair samples were subjected to trace element analysis using a flame atomic absorption spectrophotometer (Shimadzu, AA-6300) using a pre-mixed burner air-acetylene flame. The flow rates of the fuel and oxidant gases were always carefully optimized for each metal analysis. Other routine instrumental checks and calibrations were always performed on the spectrometer before use to ensure the accuracy, reliability and consistent performance of the spectrometer. Each sample was analyzed in triplicate and the averages of the trace element concentrations in the hair samples were calculated using the constructed calibration curves and listed in Table $\mathbf{1 .}$ All necessary precautions were also observed to ensure the accuracy of the results of this study. First, the acetone and ethanol used for the hair wash were of spectroscopic grade. Second, the highest purity $\mathrm{HNO}_{3}$ acid (purity, 99.999\%) was used for the hair digestion and standard solution preparations. Also, all glassware including the sample containers, digestion flasks, and volumetric flasks were pre-soaked in 6M nitric acid for three days and thoroughly rinsed with deionized water before use to remove impurities and contaminants. Additionally, all trace element sample analyses were blank subtracted.

A recovery study was also performed for each metal to further evaluate the accuracy and reliability of the results of the heavy metal concentrations obtained in the analysis. The recovery study was performed by randomly spiking ten previously analyzed hair samples with a known concentration of metal standard solution. The spiked samples were then subjected to $\mathrm{HNO}_{3}$ digestion and metal analysis procedures under the same experimental conditions as previously used for hair sample analysis. The recovery of the metals in the spiked samples was evaluated by com- paring the known concentration of the spiked metal with the concentration detected using FAAS spectrometer.

\subsection{Multivariate Analysis: Regression and Principal Component Analysis}

Linear regression and multivariate principal component analysis for pattern recognition of the levels of the metals in human scalp hair was performed using chemometric software (The Unscrambler, CAMO Inc., 9.4).

\section{Results and Discussion}

\subsection{Calibration Curves}

Table 1 presents the results of the calibration curve parameters constructed for the investigated trace elements in the hair samples. The table indicates the wavelength used for the AAS elemental analysis, the limits of detection (LOD), and limits of quantitation (LOQ) of the trace elements analyzed. The LOD, which is defined as the minimum detectable amount of metal, was calculated using the equation: LOD $=3 \mathrm{~s} / \mathrm{m}$; where $s$ is the signal of the blank and $m$ is the slope of the calibration curve. The limit of quantitation, defined as the lowest measurable concentration of analytes (trace elements in this study), was evaluated using the formula: $L O Q=10 \mathrm{~s} / \mathrm{m}$. The parameters used to calculate LOQ were as previously defined for LOD. The high values of the correlation coefficients $(r)$ obtained in Table 1 demonstrate good linear correlation of the absorbance with trace element concentrations.

\subsection{Overall Trace Element Concentration in Hair Samples}

The overall mean, maximum, and minimum of each trace element concentrations in hair samples are shown in Table 2 . The trace of the element concentrations varied widely in the hair samples as demonstrated by the large range of trace element concentrations. The order of the mean trace

Table 1. Linear regression equation, linear correlation coefficient $(R)$ of calibration curves, wavelength of detection, limit of detection (LOD), and limit of quantitation (LOQ) obtained for each element.

\begin{tabular}{cccccc}
\hline Element & Regression equation & $\mathbf{R}$ & Wavelength $(\mathbf{n m})$ & LOD $(\boldsymbol{\mu g} / \mathbf{g})$ & LOQ $(\boldsymbol{\mu g} / \mathbf{g})$ \\
\hline $\mathrm{Fe}$ & $\mathrm{y}=0.0040 \mathrm{x}+0.0048$ & 0.999 & 248.3 & 0.080 & 0.25 \\
$\mathrm{Cd}$ & $\mathrm{y}=0.087 \mathrm{x}+0.29$ & 0.973 & 228.8 & 0.030 & 0.11 \\
$\mathrm{Ca}$ & $\mathrm{y}=0.026 \mathrm{x}+0.0014$ & 0.999 & 422.7 & 0.010 & 0.040 \\
$\mathrm{Zn}$ & $\mathrm{y}=0.080 \mathrm{x}+0.77$ & 0.922 & 213.9 & 0.030 & 0.13 \\
$\mathrm{Cu}$ & $\mathrm{y}=0.092 \mathrm{x}+0.055$ & 0.999 & 309.93 & 0.030 & 0.12 \\
$\mathrm{~Pb}$ & $\mathrm{y}=0.0097 \mathrm{x}+0.0029$ & 0.998 & 283.3 & 0.030 & 0.10 \\
$\mathrm{Mg}$ & $\mathrm{y}=0.060 \mathrm{x}+1.6$ & 0.998 & 285.2 & 0.050 & 0.16 \\
$\mathrm{Cr}$ & $\mathrm{y}=0.0065 \mathrm{x}+0.0048$ & 0.981 & 357.9 & 0.050 & 0.16 \\
\hline
\end{tabular}


Table 2. Overall average of trace element concentration in human hair.

\begin{tabular}{cccccccccc}
\hline & \multicolumn{7}{c}{ Concentration $(\mu \mathrm{g} / \mathrm{g})$} \\
\cline { 2 - 9 } & $\mathrm{Fe}$ & $\mathrm{Ca}$ & $\mathrm{Cd}$ & $\mathrm{Zn}$ & $\mathrm{Cu}$ & $\mathrm{Mg}$ & $\mathrm{C}$ & $\mathrm{Pb}$ \\
\hline Average & 25 & 710 & $<0.03$ & 190 & 12 & 120 & 0.20 & $<0.030$ \\
Maximum & 460 & 3900 & $<0.03$ & 800 & 140 & 710 & 4.5 & $<0.030$ \\
Minimum & 6.2 & 2.1 & $<0.03$ & 0 & 0 & 0 & 0 & $<0.030$ \\
\hline
\end{tabular}

element concentrations in the hair sample is $\mathrm{Ca}>\mathrm{Zn}>$ $\mathrm{Mg}>\mathrm{Fe}>\mathrm{Cu}>\mathrm{Cr}$. Overall mean concentrations of $\mathrm{Ca}$ $(710 \mu \mathrm{g} / \mathrm{g}), \mathrm{Zn}(190 \mu \mathrm{g} / \mathrm{g}), \mathrm{Mg}(120 \mu \mathrm{g} / \mathrm{g}), \mathrm{Fe}(25 \mu \mathrm{g} / \mathrm{g})$, $\mathrm{Cu}(12 \mu \mathrm{g} / \mathrm{g})$, and $\mathrm{Cr}(0.20 \mu \mathrm{g} / \mathrm{g})$ were found in the hair samples. Similar trace element concentrations found in this study have been reported in human scalp hair in Pakistan, Russia, Spain, Tanzania, and China [36,47,52,55, 56]. The levels of $\mathrm{Cd}$ and $\mathrm{Pb}$ concentrations were below the detection limits $(<0.030 \mu \mathrm{g} / \mathrm{g})$ of the instrument in the hair samples. Unquestionably, the use of a more sensitive analytical instrument such as a graphite atomic absorption or an inductively coupled plasma atomic spectrometer will be required for $\mathrm{Cd}$ and $\mathrm{Pb}$ detection at ultra-low concentrations.

\subsection{Trace Element Concentration by Race and Sex}

The populations were subdivided into two race categories, the Caucasians (majority) and Non-Caucasians (minority) comprising of African Americans, Hispanics, and Asians. The trace element concentrations by race and sex are shown in Tables 3 and $\mathbf{4}$, respectively. Overall mean levels of Fe $(27 \mu \mathrm{g} / \mathrm{g}), \mathrm{Ca}(750 \mu \mathrm{g} / \mathrm{g}), \mathrm{Mg}(140 \mu \mathrm{g} / \mathrm{g}), \mathrm{Zn}$ $(200 \mu \mathrm{g} / \mathrm{g}), \mathrm{Cu}(14 \mu \mathrm{g} / \mathrm{g})$, and $\mathrm{Cr}(0.18 \mu \mathrm{g} / \mathrm{g})$ were obtained in Caucasians. In contrast, corresponding mean levels of Fe $(22 \mu \mathrm{g} / \mathrm{g}), \mathrm{Ca}(631 \mu \mathrm{g} / \mathrm{g}), \mathrm{Mg}(87 \mu \mathrm{g} / \mathrm{g}), \mathrm{Zn}$ $(163 \mu \mathrm{g} / \mathrm{g}), \mathrm{Cu}(6.1 \mu \mathrm{g} / \mathrm{g}), \mathrm{Cr}(0.24 \mu \mathrm{g} / \mathrm{g})$ were obtained in non-Caucasians. To evaluate the differences between the mean trace element concentrations obtained in Caucasians and non-Caucasians, the mean trace element concentrations obtained for the two race categories were subjected to a statistical student $t$-test analysis. At a $90 \%$ confidence level, there were no significant differences $(t$ $<1.645, p=0.01$ ) between the trace element concentrations obtained between Caucasians and non-Caucasians. However, at a 50\% confidence level, there were significant differences between the mean concentration of $\mathrm{Ca}$ $\left(t_{c a l} 0.84, t_{t a b} 0.674\right), \mathrm{Zn}\left(t_{c a l}, 1.602, t_{t a b} 0.674\right), \mathrm{Cu}\left(t_{c a l}\right.$, $\left.1.50, t_{\text {tab }} 0.674\right)$, and $\mathrm{Mg}\left(t_{c a l}=1.574, t_{\text {tab }}=0.674\right)$ obtained in Caucasians and non-Caucasians.

Trace element concentrations were also found to be gender dependent. Generally, the mean levels of all trace elements were significantly higher in females compared
Table 3. Trace elements concentration by race.

\begin{tabular}{|c|c|c|c|c|c|c|c|c|}
\hline & \multicolumn{8}{|c|}{ Concentration $(\mu \mathrm{g} / \mathrm{g})$} \\
\hline & $\mathrm{Fe}$ & $\mathrm{Ca}$ & $\mathrm{Cd}$ & $\mathrm{Zn}$ & $\mathrm{Cu}$ & $\mathrm{Mg}$ & $\mathrm{Cr}$ & $\mathrm{Pb}$ \\
\hline \multicolumn{9}{|c|}{ Caucasian $(\mathrm{n}=87)$} \\
\hline Average & 27 & 750 & $<0.030$ & 200 & 14 & 140 & 0.18 & $<0.030$ \\
\hline Maximum & 460 & 3400 & $<0.030$ & 820 & 140 & 710 & 3.7 & $<0.030$ \\
\hline Minimum & 6.9 & 34 & $<0.030$ & 0 & 0 & 0 & 0 & $<0.030$ \\
\hline \multicolumn{9}{|c|}{ Non-Caucasian $(\mathrm{n}=38)$} \\
\hline Average & 22 & 631 & $<0.030$ & 163 & 6.1 & 87 & 0.24 & $<0.030$ \\
\hline Maximum & 170 & 3900 & $<0.030$ & 567 & 61 & 639 & 4.5 & $<0.030$ \\
\hline Minimum & 6.2 & 2.1 & $<0.030$ & 0 & 0 & 0 & 0 & $<0.030$ \\
\hline
\end{tabular}

Table 4. Trace element concentration by sex.

\begin{tabular}{|c|c|c|c|c|c|c|c|c|}
\hline & \multicolumn{8}{|c|}{ Concentration $(\mu \mathrm{g} / \mathrm{g})$} \\
\hline & $\mathrm{Fe}$ & $\mathrm{Ca}$ & $\mathrm{Cd}$ & $\mathrm{Zn}$ & $\mathrm{Cu}$ & $\mathrm{Mg}$ & $\mathrm{Cr}$ & $\mathrm{Pb}$ \\
\hline \multicolumn{9}{|c|}{ Male $(n=60)$} \\
\hline Average & 18 & 330 & $<0.030$ & 167 & 4.034 & 27 & 0.080 & $<0.030$ \\
\hline Maximum & 170 & 1900 & $<0.030$ & 820 & 51.82 & 230 & 3.2 & $<0.030$ \\
\hline Minimum & 6.6 & 2.1 & $<0.030$ & 0 & 0 & 0 & 0 & $<0.030$ \\
\hline \multicolumn{9}{|c|}{ Female $(n=65)$} \\
\hline Average & 32 & 1100 & $<0.030$ & 210 & 19 & 210 & 0.31 & $<0.030$ \\
\hline Maximum & 460 & 3900 & $<0.030$ & 560 & 140 & 710 & 4.5 & $<0.030$ \\
\hline Minimum & 6.2 & 36 & $<0.030$ & 0 & 0 & 0 & 0 & $<0.030$ \\
\hline
\end{tabular}

to males. The mean Fe level of $32 \mu \mathrm{g} / \mathrm{g}$ found in females was approximately twice the average level of Fe $(17.80$ $\mu \mathrm{g} / \mathrm{g})$ obtained in males. Also, the mean level of $\mathrm{Mg}$ (210 $\mu \mathrm{g} / \mathrm{g}$ ) obtained in females was 7 time higher than the corresponding mean $\mathrm{Mg}$ (27) level found in males. Also, the mean levels of $\mathrm{Zn}(210 \mu \mathrm{g} / \mathrm{g}), \mathrm{Cu}(19 \mu \mathrm{g} / \mathrm{g})$, and $\mathrm{Cr}(0.31$ $\mu \mathrm{g} / \mathrm{g})$ were considerably higher than the mean levels of $\mathrm{Zn}(170 \mu \mathrm{g} / \mathrm{g}), \mathrm{Cu}(4.0 \mu \mathrm{g} / \mathrm{g})$, and $\mathrm{Cr}(0.080 \mu \mathrm{g} / \mathrm{g})$, respectively obtained in males. Interestingly, at the $90 \%$ confidence levels, the concentration of $\mathrm{Fe}, \mathrm{Ca}, \mathrm{Zn}, \mathrm{Cu}$, $\mathrm{Mg}$, and $\mathrm{Cr}$ obtained in males were significantly and statistically different $(t>1.645)$ from the corresponding level of $\mathrm{Fe}, \mathrm{Ca}, \mathrm{Zn}, \mathrm{Cu}, \mathrm{Mg}$, and $\mathrm{Cr}$ obtained in females. At the $95 \%$ confidence level, the concentration of $\mathrm{Ca}\left(t_{c a l}\right.$, $\left.=6.618, t_{\text {tab }} 1.960\right), \mathrm{Zn}\left(t_{c a l}, 2.047, t_{\text {tab }} 1.960\right), \mathrm{Cu}\left(t_{c a l}\right.$, $\left.3.107, t_{\text {tab }} 1.960\right)$, and $\mathrm{Mg}\left(t_{c a l}, 24, t_{\text {tab }} 1.960\right)$ obtained in males were also considerably different from the corresponding level found in women, demonstrating the influence of sex on the trace element concentration in human subjects. 


\subsection{Effect of Smoking Habits on Trace Element Concentration}

A summary of the levels of trace element concentrations found in the scalp hair of smokers and non-smokers are shown in Table 5. In general, the mean levels of Ca (550 $\mu \mathrm{g} / \mathrm{g})$ and $\mathrm{Mg}(77 \mu \mathrm{g} / \mathrm{g})$ in smokers were less than the mean levels of $\mathrm{Ca}(740 \mu \mathrm{g} / \mathrm{g})$ and $\mathrm{Mg}(130 \mu \mathrm{g} / \mathrm{g})$ found in non-smokers. Also, the levels of $\mathrm{Cu}(2.5 \mu \mathrm{g} / \mathrm{g}), \mathrm{Zn}$ $(170 \mu \mathrm{g} / \mathrm{g})$, and $\mathrm{Cr}(0.14 \mu \mathrm{g} / \mathrm{g})$ found in smokers were relatively less than the corresponding levels of $\mathrm{Cu}$ (13 $\mu \mathrm{g} / \mathrm{g}), \mathrm{Zn}(190 \mu \mathrm{g} / \mathrm{g})$, and $\mathrm{Cr}(0.21 \mu \mathrm{g} / \mathrm{g})$ found in nonsmokers. Other studies have reported similar low concentrations of $\mathrm{Ca}, \mathrm{Mg}, \mathrm{Cu}$, and $\mathrm{Zn}$ in smokers scalp hair compared to non-smokers in Poland [50]. However, at $95 \%$ confidence level, the mean level of Fe $(40 \mu \mathrm{g} / \mathrm{g})$ found in smokers in this study was statistically and significantly higher than the corresponding mean Fe level of $23 \mu \mathrm{g} / \mathrm{g}$ obtained in non-smokers $\left(t_{c a l} 2.12, t_{\text {tab }} 1.960\right)$.

\subsection{Trace Element Concentration by Age}

To evaluate the effect of age on trace element concentration, the sample populations were subdivided into two age group categories. The first age group category consists of people between $1-20$ years old $(n=29)$, while the second age group category is made up of people 21 years and older $(n=96)$. Table 6 shows the results of the trace element concentrations by age. The concentrations of Fe ranged between $6.9 \mu \mathrm{g} / \mathrm{g}$ and $220 \mu \mathrm{g} / \mathrm{g}$ in the $1-20$ years old age group while the concentrations of $\mathrm{Fe}$ ranged between $6.155 \mu \mathrm{g} / \mathrm{g}$ and $460 \mu \mathrm{g} / \mathrm{g}$ in people 21 years and older. There was no significant difference between the mean Fe level of $26 \mu \mathrm{g} / \mathrm{g}$ obtained in $1-20$ years old age group and mean Fe level of $25 \mu \mathrm{g} / \mathrm{g}$ obtained in people 21 years and older. However, at the $95 \%$ confidence level, a considerably higher mean $\mathrm{Ca}$ concentration of $800 \mu \mathrm{g} / \mathrm{g}$ was obtained in 21 people years

Table 5. Effect of smoking habit of trace element concentration.

\begin{tabular}{cccccccccc}
\hline \multicolumn{1}{c}{ Concentration $(\mu \mathrm{g} / \mathrm{g})$} \\
\hline & $\mathrm{Fe}$ & $\mathrm{Ca}$ & $\mathrm{Cd}$ & $\mathrm{Zn}$ & $\mathrm{Cu}$ & $\mathrm{Mg}$ & $\mathrm{Cr}$ & $\mathrm{Pb}$ \\
\hline \multicolumn{7}{c}{ Smokers $(\mathrm{n}=18)$} \\
Average & 40 & 550 & $<0.030$ & 170 & 2.5 & 77 & 0.14 & $<0.030$ \\
Maximum & 460 & 1600 & $<0.030$ & 600 & 13 & 330 & 1.5 & $<0.030$ \\
Minimum & 7.5 & 2.1 & $<0.030$ & 0 & 0 & 0 & 0 & $<0.030$ \\
& & & Non-smokers $(\mathrm{n}=107)$ & & & \\
Average & 23 & 740 & $<0.030$ & 190 & 13 & 130 & 0.21 & $<0.030$ \\
Maximum & 220 & 3900 & $<0.030$ & 820 & 140 & 710 & 4.5 & $<0.030$ \\
Minimum & 6.2 & 31 & $<0.030$ & 0 & 0 & 0 & 0 & $<0.030$ \\
\hline
\end{tabular}

Table 6. Trace elements concentration by age group.

\begin{tabular}{cccccccccc}
\hline & \multicolumn{8}{c}{ Concentration $(\mu \mathrm{g} / \mathrm{g})$} \\
\cline { 2 - 9 } & $\mathrm{Fe}$ & $\mathrm{Ca}$ & $\mathrm{Cd}$ & $\mathrm{Zn}$ & $\mathrm{Cu}$ & $\mathrm{Mg}$ & $\mathrm{Cr}$ & $\mathrm{Pb}$ \\
\hline \multirow{7}{*}{ Age $1-20(\mathrm{n}=29)$} \\
Average & 26 & 400 & $<0.030$ & 200 & 20 & 50 & 0.21 & $<0.030$ \\
Maximum & 220 & 1300 & $<0.030$ & 360 & 140 & 300 & 3.2 & $<0.030$ \\
Minimum & 6.9 & 36 & $<0.030$ & 37 & 0 & 0 & 0 & $<0.030$ \\
& Age 21 and older $(\mathrm{n}=96)$ & & & & \\
Average & 25 & 800 & $<0.030$ & 180 & 9.3 & 140 & 0.20 & $<0.030$ \\
Maximum & 460 & 3900 & $<0.030$ & 820 & 130 & 710 & 4.5 & $<0.030$ \\
Minimum & 6.2 & 2.1 & $<0.030$ & 0 & 0 & 0 & 0 & $<0.030$ \\
\hline
\end{tabular}

and older as compared to a relatively low average $\mathrm{Ca}$ level of $400 \mu \mathrm{g} / \mathrm{g}$ obtained in the $1-20$ years old age group $\left(t_{c a l} 2.686, t_{t a b} 1.965\right)$. In addition, the mean level of $\mathrm{Mg}(142.4 \mu \mathrm{g} / \mathrm{g})$ in older people is significantly higher than the mean Mg level of 50.11 obtained in the $1-20$ years old age group $\left(t_{c a l}=2.780, t_{t a b}=1.965\right)$. In addition, the level of $\mathrm{Cu}(19.61 \mu \mathrm{g} / \mathrm{g})$ found in $1-20$ years old age group was considerably higher than the $\mathrm{Cu}(9.3 \mu \mathrm{g} / \mathrm{g})$ found in people 21 years and older $\left(t_{c a l}=2.27, t_{t a b}=\right.$ 1.965). In contrast, there was no statistical difference between mean levels of $\mathrm{Zn}(200 \mu \mathrm{g} / \mathrm{g})$ mean levels of $\mathrm{Zn}$ $(180 \mu \mathrm{g} / \mathrm{g})$ found in people 21 years and older $\left(t_{c a l}=\right.$ $\left.0.863, t_{t a b}=1.965\right)$. Also, there was no significant different between the mean level of $\mathrm{Cr}$ of $0.21 \mu \mathrm{g} / \mathrm{g}$ and $0.20 \mu \mathrm{g} / \mathrm{g}$, respectively, obtained in the $1-20$ years old age group and older people $\left(t_{c a l}=0.034, t_{t a b}=1.965\right)$. Results of the trace element concentrations in this study are similar to the trace element concentrations reported in young people in Spain [55].

\section{6. $\mathrm{Ca} / \mathrm{Mg}$ and $\mathrm{Zn} / \mathrm{Cu}$ Ratio}

The ratios of $\mathrm{Ca} / \mathrm{Mg}$ and $\mathrm{Zn} / \mathrm{Cu}$ in hair samples are often used to evaluate $\mathrm{Ca}$ absorption and $\mathrm{Cu}$ utilization in humans. The ratios are also used as markers for various health related issues including, atherosclerosis, hypertension diabetics, insulin sensitivity, and pancreatic cancer. The utilization and absorption of $\mathrm{Ca}$ is highly dependent on $\mathrm{Mg}$ concentration (Toba et al., 1999). In general, a low $\mathrm{Ca} / \mathrm{Mg}$ ratio is preferred for proper bodily function and $\mathrm{Ca}$ metabolism. An ideal normal $\mathrm{Ca} / \mathrm{Mg}$ ratio of 2 in humans has been suggested. At elevated Mg concentrations, the absorption of $\mathrm{Ca}$ is severely hindered [58]. More importantly, a high $\mathrm{Ca} / \mathrm{Mg}$ concentration ratio has been associated with various health issues, including, atherosclerosis and hypertension [59,60]. Additionally, $\mathrm{Ca} / \mathrm{Mg}$ imbalances may lead to other health related issues such as diabetics and alterations in insulin sensitivity [61] necessi- 
tating the need to critically evaluate the $\mathrm{Ca} / \mathrm{Mg}$ ratio in humans. Table 7 shows the $\mathrm{Ca} / \mathrm{Mg}$ ratio in the hair samples to be 5.9. The calculated $\mathrm{Ca} / \mathrm{Mg}$ ratio was also found to depend on age, sex, race, and smoking habits. Generally, the $\mathrm{Ca} / \mathrm{Mg}$ ratio in older people is less than the $\mathrm{Ca} /$ $\mathrm{Mg}$ ratio found in younger people. Also, non-Caucasians have a relatively larger $\mathrm{Ca} / \mathrm{Mg}$ ratio of 7.2 compared to a $\mathrm{Ca} / \mathrm{Mg}$ ratio of 5.5 found in Caucasians. The $\mathrm{Ca} / \mathrm{Mg}$ ratio (12) found in males was twice the corresponding $\mathrm{Ca} / \mathrm{Mg}$ ratio of 5.1 found in females. Smoking also seems to influence the $\mathrm{Ca} / \mathrm{Mg}$ ratio. The $\mathrm{Ca} / \mathrm{Mg}$ ratio (7.2) in smokers is larger than the $\mathrm{Ca} / \mathrm{Mg}$ ratio of 5.8 found in nonsmokers. Other studies have also reported similarly higher $\mathrm{Ca} / \mathrm{Mg}$ ratios in hair samples of smokers compared to non-smokers [50].

Accurate knowledge of $\mathrm{Zn}$ to $\mathrm{Cu}$ concentration ratios in humans is also of critical health importance because a high $\mathrm{Zn} / \mathrm{Cu}$ ratio may influence the utilization of $\mathrm{Cu}$, resulting in $\mathrm{Cu}$ deficiency in the body. For example, reduced erythrocyte copper-zinc superoxide dismutase activity at elevated $\mathrm{Zn}$ plasma concentrations has been reported [62]. Additionally, elevated $\mathrm{Zn}$ concentrations have been linked to significant reductions in $\mathrm{Cu}$ plasma caeruloplasmin, serious anemia, and alterations in immune responses and serum lipids [63-65]. Besides, an increase in the $\mathrm{Zn} / \mathrm{Cu}$ ratio has been observed in pancreatic cancer patients compared to healthy humans [66].

The $\mathrm{Zn} / \mathrm{Cu}$ concentration ratios in hair samples by age group, sex, race, and smoking habit are presented in Table 7. A higher $\mathrm{Zn} / \mathrm{Cu}$ concentration ratio of 69 was found in smokers compared to $\mathrm{Zn} / \mathrm{Cu}$ ratio of 14 found in non-smokers. The $\mathrm{Zn} / \mathrm{Cu}$ ratio of 20 found in older people was also significantly larger than the $\mathrm{Zn} / \mathrm{Cu}$ ratio of 10 observed in younger people. However, Caucasians have relatively low $\mathrm{Zn} / \mathrm{Cu}$ ratio (14) compared to the $\mathrm{Zn}$ / $\mathrm{Cu}$ ratio of 27 found in non-Caucasians. Also, a female's scalp hair contained a low $\mathrm{Zn} / \mathrm{Cu}$ ratio of 11 compared

Table 7. Ca/Mg and $\mathrm{Zn} / \mathrm{Cu}$.

\begin{tabular}{ccc}
\hline Category & $\mathbf{C a} / \mathbf{M g}$ ratio & $\mathbf{Z n / C u}$ ratio \\
\hline $\begin{array}{c}\text { Younger people } \\
(1 \text { - 20 years age group) }\end{array}$ & 8.1 & 10 \\
Older people & 5.6 & 20 \\
(older than 21 years age group) & 5.5 & 14 \\
Caucasian & 7.2 & 27 \\
Non-Caucasian & 7.2 & 70 \\
Smokers & 5.8 & 14 \\
Non-smokers & 12 & 40 \\
Males & 5.1 & 11 \\
Females & 5.9 & 16 \\
Overall & &
\end{tabular}

with a high $\mathrm{Zn} / \mathrm{Cu}$ ratio of 40 found in male scalp hair samples.

\subsection{Analytical Method Validation and Recovery Study}

Commercial human hair trace element reference standards were not readily available, consequently a spike recovery was performed to evaluate the accuracy of the results obtained from this study. The results of the recovery study performed for each metal analysis in the hair samples are presented in Table 8. Overall, the percentage recovery of the metal analysis in the hair samples ranged between $95 \%$ and $104 \%$. The percent recovery obtained in this study falls within the normal acceptable range of $90 \%-110 \%$ for a good recovery study. The high percentage recovery obtained from the study validates the accuracy of the method and the reliability of the levels of metal concentration in this study. In addition, the obtained high recovery demonstrates insignificant loss or addition of metals to the hair samples during the sample preparation, sample digestion or instrumental metal analysis procedures.

\subsection{Linear Regression and Principal Component Analysis}

To further gain a better insight and understanding of the inter-element association of trace elements in the scalp hair samples, the levels of trace elements were subjected to a linear regression and principal component analysis $(P C A)$. Table 9 presents the summary of the correlation coefficients $(r)$ of the inter-element associations in the hair samples. Generally, the levels of the trace elements in hair samples were poorly correlated. However, significant correlations were found between $\mathrm{Ca}$ and $\mathrm{Mg}(r=$ $0.840, p=0.05$ ). Poor correlation between the levels of trace elements in hair suggests that there may be no particular common source of the trace elements in the hair.

Table 8. Recovery study for FAAS metal analysis in hair samples.

\begin{tabular}{cc}
\hline Metal & \% Recovery \\
\hline $\mathrm{Pb}$ & 96.0 \\
$\mathrm{Cd}$ & 94.6 \\
$\mathrm{Fe}$ & 97.8 \\
$\mathrm{Ca}$ & 102.4 \\
$\mathrm{Mg}$ & 98.1 \\
$\mathrm{Zn}$ & 95.2 \\
$\mathrm{Cu}$ & 104.1 \\
$\mathrm{Cr}$ & 102.4 \\
\hline
\end{tabular}


Table 9. Correlation coefficient ( $r$ ) values of the association between trace elements in human hair samples.

\begin{tabular}{ccccccc}
\hline & $\mathrm{Fe}$ & $\mathrm{Ca}$ & $\mathrm{Mg}$ & $\mathrm{Zn}$ & $\mathrm{Cu}$ & $\mathrm{Cr}$ \\
\hline $\mathrm{Fe}$ & & 0.171 & 0.092 & 0.035 & 0.037 & 0.154 \\
$\mathrm{Ca}$ & 0.171 & & $\mathbf{0 . 8 4 0}$ & 0.174 & 0.105 & 0.044 \\
$\mathrm{Mg}$ & 0.092 & $\mathbf{0 . 8 4 0}$ & & 0.217 & 0.102 & 0.055 \\
$\mathrm{Zn}$ & 0.035 & 0.174 & 0.217 & & 0.082 & 0.050 \\
$\mathrm{Cu}$ & 0.037 & 0.105 & 0.102 & 0.082 & & -0.042 \\
$\mathrm{Cr}$ & 0.154 & 0.044 & 0.055 & 0.050 & -0.042 & \\
\hline
\end{tabular}

Diet, eating habits, and the use of food supplements varies widely among people; therefore, people may obtain the required trace elements from diverse sources, resulting in the poor correlation of trace elements in hair samples. Similar poor inter-element associations in hair samples have also been observed and reported elsewhere [66].

Principal component analysis is a modern chemometric approach often employed for pattern recognition in a complex data set. $P C A$ is often used to obtain hidden information that is not apparent from a conventional data analysis. Detailed mathematical discussions and procedures of $P C A$ have been widely reported [67-69] and is beyond the scope of this study. In brief, $P C A$ is usually performed by transforming the original data set or matrix from the initial coordinate system made up of $n$-variables into a new orthogonal coordinate system. The new variable space is typically composed of a smaller number of orthogonal vectors known as principal components $(P C s)$. For example, a set of data with $n$-variables $(n=6$ in this study, corresponding to the number of trace elements determined in hair samples) will require an $n$-dimensional coordinate system, known as variable space to represent it. The most vital assumption of multivariate analysis is that the directions with maximum variance in a data set are associated with useful information. Consequently, the first principal component $(P C l)$ is drawn through the variable space in the direction of the maximum variance in of the original data set. The second principal component $(P C 2)$ is then drawn through the data set in the direction of the next largest variance, so that $P C 1$ and $P C 2$ are orthogonal to each other. The third principal component $(P C 3)$ is subsequently drawn so that $P C 1, P C 2$, and $P C 3$ are all orthogonal to each other. Thus, $P C 1, P C 2$, and $P C 3$ now represent a set of variance-scaled eigenvectors that provide a new orthogonal coordinate system on which the original data set can be represented. The individual principal components can be calculated as shown in Equation (1). Each $P C$ is a linear combination of the n-vectors that make up the original variable space.

$$
P C 1=P_{11} X_{1}+P_{21} X_{2}+P_{31} X_{3}+L+P_{n 1} X_{n}
$$

where, $P C 1$ is the first principal component and $X_{1}, X_{2}$, $X_{3}, \ldots X_{n}$, are the magnitudes of the levels of trace elements in this study, and the coefficients $\left(P_{I j}\right)$ of the linear combination are called $x$-loadings. The coordinates of the data on the new PCs coordinate system $\left(t_{i}\right)$ are referred to as scores. The magnitude of the scores reveals the importance of $P C_{i}$ to that data point. Groupings of data points on the scores plot may reveal obscured structure in the data. Consequently, new insight is often gained as new relationships that were formerly obscured in the old coordinate system are revealed, allowing pattern recognition in a data set. The use of $P C A$ for data analysis is desirable because it often reduces the dimensionality of the data set to a much smaller value.

The results of the PCA shows that the first two PCs accounted for $98 \%$ of the variability in the levels of trace element in the hair samples. Therefore, two PCs (PC1 and $P C 2$ ) are adequate to represent the data set. Equations (2) and (3) show a mathematical expression for $P C 1$, and $P C 2$, respectively obtained from the hair analysis in this study.

$$
\begin{aligned}
P C 2= & -5.165 e^{-3}[\mathrm{Fe}]-6.477 e^{-2}[\mathrm{Ca}]+0.979[\mathrm{Zn}] \\
& +1.659 e^{-2}[\mathrm{Cu}]+0.195[\mathrm{Mg}]+2.770 e^{-4}[\mathrm{Cr}] \\
P C 2= & -5.165 e^{-3}[\mathrm{Fe}]-6.477 e^{-2}[\mathrm{Ca}]+0.979[\mathrm{Zn}] \\
& +1.659 e^{-2}[\mathrm{Cu}]+0.195[\mathrm{Mg}]+2.770 e^{-4}[\mathrm{Cr}]
\end{aligned}
$$

Figure 1(a) is the $x$-loading of the plot of $P C 1$ versus the $P C 2$. While all the trace elements are important, calcium and magnesium were found to be the most significant elements, contributing to the $P C 1$, with $x$-loading values of 0.98 and 0.18 , respectively. However, $\mathrm{Zn}$ and $\mathrm{Mg}$ were found to be the major contributors to $P C 2$, with $x$-loading values of 0.98 and 0.20 respectively. It is very interesting to note that, the overall calculated $\mathrm{Ca} / \mathrm{Mg}$ ratio value of 5.87 in Table 7 was similar to the corresponding $x$-loading $\mathrm{Ca} / \mathrm{Mg}$ ratio of 5.3 obtained from $P C A$. However, the $x$-loading $\mathrm{Zn} / \mathrm{Cu}$ ratio of 59 obtained from $P C A$ was significantly larger than the corresponding overall $\mathrm{Zn} / \mathrm{Cu}$ ratio value of 16.0 obtained in Table 7 . These differences may be associated with a wider range of $\mathrm{Zn} / \mathrm{Cu}$ ratio (69 - 10) obtained for different categories of people in Table 7. Nontheless, further critical observation of the data revealed that the $x$-loading $\mathrm{Zn} / \mathrm{Cu}$ ratio of 59 was similar to the average $\mathrm{Zn} / \mathrm{Cu}$ ratio value of 54 obtained in smokers (69) and in men (40). With further study and more data analysis, the ratio of the $x$-loadings value of $\mathrm{Ca} / \mathrm{Mg}$ and $\mathrm{Zn} / \mathrm{Cu}$ from $P C A$ can therefore be potentially used for rapid screening of calcium and copper utilization and for medical diagnosis of people for suseptiability to atherosclerosis, hypertension diabetics, insulin sensitivity, and pancreatic cancer. 


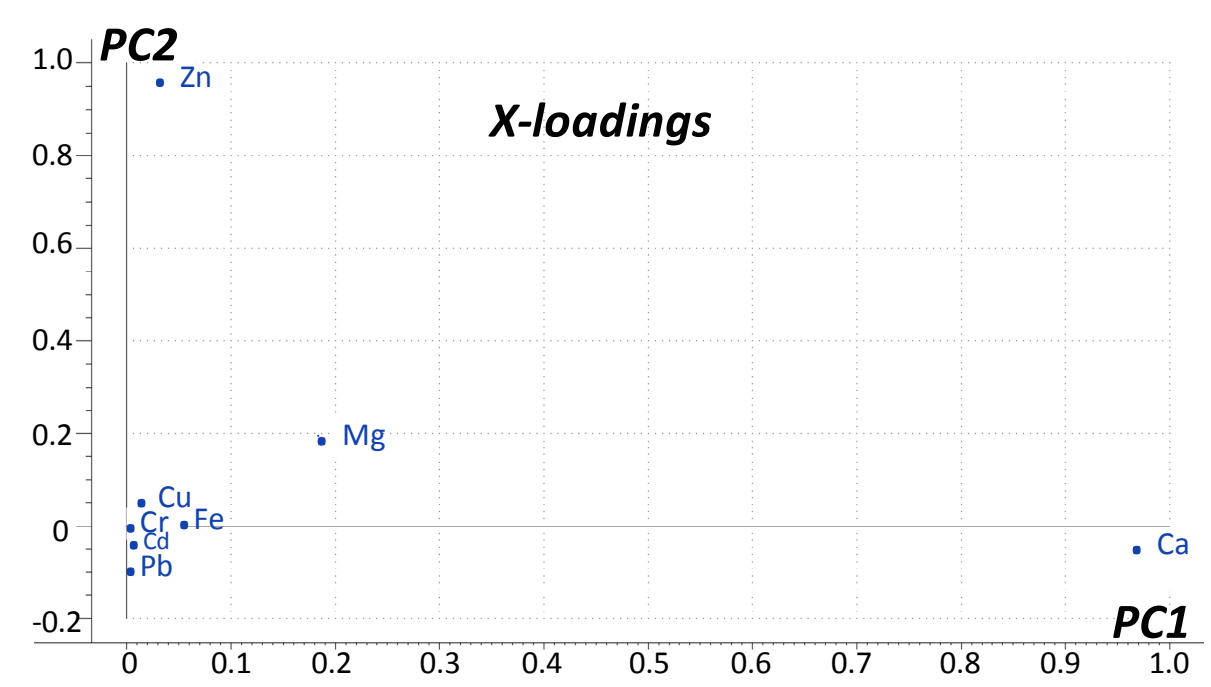

(a)

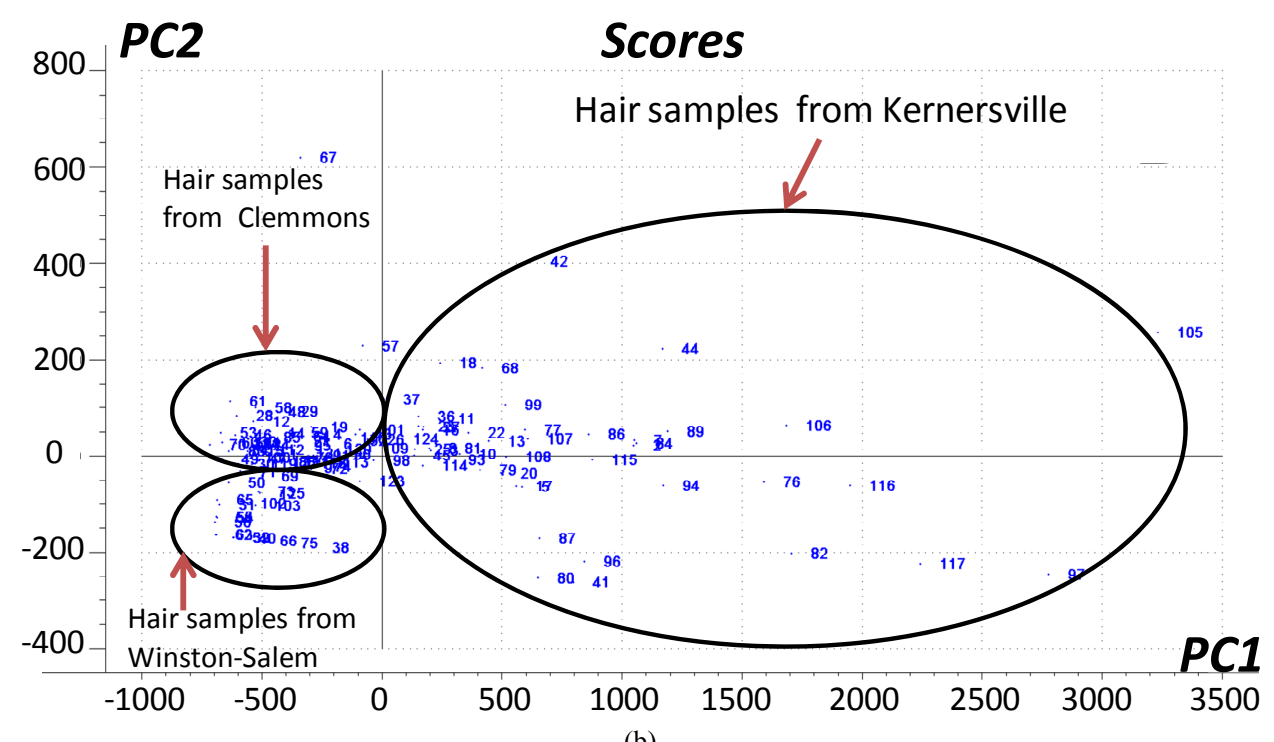

(b)

Figure 1. (a) X-loadings of the plot of PC2 versus PC1; (b) Scores plot the second principal component (PC2) versus the first principal component (PC1).

Figure 1(b) is the scores plot of the $P C 1$ versus $P C 2$. A closer examination of the plot reveals an interesting pattern with groupings of hair samples based on the locations where the hair samples were collected. The numbers in the plots are the different number codes assigned to different hair samples. For example, hair samples collected in Kernersville were grouped together in the first and second quadrants in Figure 1(b). However, hair samples collected in Winston-Salem and Clemmons were similarly grouped together in the lower left of the figure in the third and fourth quadrant, respectively, in Figure 1(b). Other studies have reported the practical application of $P C A$ in elemental analysis for pattern recognition to differentiate and ascertain the origin of several agricultural products $[70,71]$.

\section{Conclusion}

The results of the flame atomic absorption spectroscopic determination of trace elements in human scalp hair were reported. The levels of trace elements in hair samples were further subjected to linear regression and principal component analysis for data analysis and pattern recognition. The result of this study showed wide variation in trace element concentrations in human scalp hair which may be attributed to differences in eating habits. In addition, trace element concentrations were found to be highly dependent on age, sex, race, and smoking habits. Cadmium and $\mathrm{Pb}$ were below the detection limit of 0.030 $\mu \mathrm{g} / \mathrm{g}$ in the hair samples. Overall, the levels of trace element concentrations in this study were within the expected normal range of healthy humans and similar to report- 
ed levels of trace element concentrations in healthy individuals elsewhere. Future study will include comparative analysis and determination of trace element concentrations in human scalp hair of cancer, diabetics, and obesity patients. The results of these findings will be communicated in future manuscripts.

\section{Acknowledgements}

The authors acknowledge financial support from National Science Foundation HBCU-UP Award \# HRD0927905, US Department of Education, Title III grant to Winston Salem State University.

\section{REFERENCES}

[1] K. M. Hambidge, "Trace Elements in Human and Animal Nutrition," 5th Edition, Academic Press, San Diego, 1987.

[2] World Health Organization, "Trace Elements in Human Nutrition and Health," WHO, Geneva, 1996.

[3] Institute of Medicine, "Food and Nutrition Board. Dietary Reference Intakes for Vitamin A, Vitamin K, Arsenic, Boron, Chromium, Copper, Iodine, Iron, Manganese, Molybdenum, Nickel, Silicon, Vanadium and Zinc," National Academy Press, Washington DC, 2001.

[4] M. Luno, P. Roncales and D. Djenane, "Beltran, Beef Shelf Life in Low $\mathrm{O}_{2}$ and High $\mathrm{CO}_{2}$ Atmospheres Containing Different Low CO Concentrations," Meat Science, Vol. 55, No. 4, 2000, pp. 413-419. doi:10.1016/S0309-1740(99)00170-9

[5] M. Seyfert, R. A. Mancini, M. C. Hunt, J. Tang, C. Faustman, "Influence of Carbon monoxide in Package Atmospheres Containing Oxygen on Color, Reducing Activity, and Oxygen Consumption of Five Bovine Muscles," Meat Science, Vol. 75, No. 3, 2007, pp. 432-442. doi:10.1016/j.meatsci.2006.08.007

[6] D. Voet, J. G. Voet and C. W. Pratt, "Fundamentals of Biochemistry: Life at the Molecular Level," 3rd Edition, John Wiley \& Sons, Inc., Hoboken, 2008.

[7] J. Y. Jeong and J. R. Claus, "Color Stability and Reversion in Carbon Monoxide Packaged Ground Beef," Meat Science, Vol. 85, No. 3, 2010, pp. 525-530. doi:10.1016/j.meatsci.2010.02.027

[8] H. Tapiero, L. Gate and K. D. Tew, "Iron: Deficiencies and Requirements," Biomedicine \& Pharmacotherapy, Vol. 55, No. 6, 2001, pp. 324-332. doi:10.1016/S0753-3322(01)00067-1

[9] S. Huang, Y. Yang, C. Cheng, J. Chen and C. Lin, "The Etiology and Treatment Outcome of Iron Deficiency and Iron Deficiency Anemia in Children," Journal of Pediatric Hematology/Oncology, Vol. 32, No. 4, 2010, pp. 282-285. doi:10.1097/MPH.0b013e3181d69b2b

[10] N. Fabris and F. Mocchegiani, "Zinc, Human Diseases and Aging," Aging Clinical and Experimental Research, Vol. 7, No. 2, 1995, pp. 77-93. doi:10.1007/BF03324297

[11] G. Vivoli, M. Bergomi, P. Borella, G. Fantuzzi and E.
Caselgrandi, "Cadmium in Blood, Urine and Hair Related to Human Hypertension," Journal of Trace Elements and Electrolytes in Health and Disease, Vol. 3, No. 3, 1989, pp. 139-145.

[12] J. Schwartz, "Low-Level Lead Exposure and Children's IQ: A Meta-Analysis and Search for a Threshold," Environmental Research, Vol. 65, No. 1, 1994, pp. 42-55. doi:10.1006/enrs.1994.1020

[13] S. Tong, Y. E. von Schirnding and T. Prapamontol, "Environmental, Lead Exposure: A Public Health Problem of Global Dimensions," Bulletin of World Health Organization, Vol. 78, No. 9, 2000, pp. 1068-1077.

[14] Agency for Toxic Substances and Diseases Registry, "Toxicological Profile for Lead," US Department of Health and Human Services, Public Health Services, 2005. http://www.atsdr.cdc.gov/toxprofiles/tp13.pdf

[15] G. Hotter, L. M. Fels, D. Closa, J. Rosello, H. Stolte and E. Gelpi, "Altered Levels of Urinary Prostanoids in LeadExposed Workers," Toxicology Letter, Vol. 77, No. 1-3, 1995, pp. 309-312. doi:10.1016/0378-4274(95)03311-4

[16] M. P. Nava-Hernandez, L. A. Hauad-Marroquin, S. BassolMayagoitia, G. Garcia-Arenas, R. Mercado-Hernandez, M. A. Echavarri-Guzman and R. M. Cerda-Flores, "Lead, Cadmium, and Arsenic-Induced DNA Damage in Rat Germinal Cells," DNA Cell Biology, Vol. 28, No. 5, 2009, pp. 241-248. doi:10.1089/dna.2009.0860

[17] Y. von Schirnding, A. Mathee, M. Kibel, P. Robertson, N. Strauss and R. A. Blignaut, "Study of Pediatric Blood Levels in a Mining Area in South Africa," Environmental Research, Vol. 93, No. 3, 2003, pp. 259-263. doi:10.1016/S0013-9351(03)00117-8

[18] G. C. Lough, J. J. Schauer, J. Park, M. M. Shafer, J. T. DeMinter and J. P. Weinstein, "Emissions of Metals Associated with Motor Vehicle Roadways," Environmental Chemistry and Technology, Vol. 39, No. 3, 2005, pp. 826836.

[19] J. Nriagu, N. Oleru, C. Cudioe and A. Chine, "Lead Poisoning of Children in Africa, III. Kaduna, Nigeria," Science of the Total Environment, Vol. 197, No. 1-3, 1997, pp. 13-19. doi:10.1016/S0048-9697(96)05408-3

[20] P. C. Onianwa and S. O. Fakayode, "Lead Contamination of Topsoil and Vegetation in the Vicinity of a Battery Factory in Nigeria," Environmental Geochemistry and Health, Vol. 22, No. 3, 2000, pp. 211-218. doi:10.1023/A:1026539531757

[21] O. E. Orisakwe, "Environmental Pollution and Blood Lead Levels in Nigeria: Who Is Unexposed?" International Journal of Occupational and Environmental Health, Vol. 15, No. 3, 2009, pp. 315-317. doi:10.1179/107735209799239007

[22] J. E. Fergusson, K. A. Hibbard and R. L. H. Ting, "Lead in Human Hair: General Survey-Battery Factory Employees and Their Families," Environmental Pollution (Ser B), Vol. 2, No. 3, 1981, pp. 235-248. doi:10.1016/0143-148X(81)90021-5

[23] S. O. Fakayode and B. I. Olu-Owolabi, "Heavy Metal Contamination of Roadside Topsoil in Osogbo, Nigeria: Its Relationship to Traffic Density and Proximity to High- 
ways," Environmental Geology, Vol. 44, No. 2, 2003, pp. 150-157.

[24] S. Bakirdere and M. Yaman, "Determination of Lead, Cadmium and Copper in Roadside Soil and Plants in Elazig, Turkey," Environmental Monitoring and Assessment, Vol. 136, No. 1-3, 2008, pp. 401-410. doi:10.1007/s10661-007-9695-1

[25] K. Suzuki, T. Yabuki and Y. Ono, "Roadside Rhododendron Pulchrum Leaves as Bioindicators of Heavy Metal Pollution in Traffic Areas of Okayama, Japan," Environmental Monitoring and Assessment, Vol. 149, No. 1-4, 2009, pp. 133-141. doi:10.1007/s10661-008-0188-7

[26] H. W. Mielke, D. Dugas, P. W. Mielke, K. S. Smith, S. L. Smith and C. R. Gonzales, "Association between Soil and Soil Lead and Childhood Blood Lead in Urban New Orleans and Rural Lafourche Parish of Louisiana," Environmental Health Perspectives, Vol. 105, No. 4, 1997, pp. 950-954. doi:10.1289/ehp.97105950

[27] U. Ranft, T. Delschen, M. Machtolf, D. Sugiri and M. Wilhelm, "Lead Concentration in the Blood of Children and Its Association with Lead in Soil and Ambient Air. Trends between 1983 and 2000 in Duisburg," Journal of Toxicology and Environmental Health, Part A, Vol. 71, No. 11-12, 2008, pp. 710-715. doi:10.1080/15287390801985117

[28] A. Kumar and P. Pastore, "Lead and Cadmium in Soft Plastic Toys," Current Science India, Vol. 93, No. 6, 2007, pp. 818-822.

[29] European Standard EN 71-3, "Safety of Toys-Part 3, Migration of Certain Elements," 1994.

[30] Consumer Product Safety Commission, "Determination of Safe Levels of Lead in Paints," Federal Register, Vol. 42, No. 32, 1977, pp. 9404-9406.

[31] A. Leibovitz, E. Lubart, J. Wainstein, Y. Dror and R. Segal, "Serum Trace Elements in Elderly Frail Patients with Oropharyngeal Dysphagia," Journal of Nutritional Science and Vitaminology, Vol. 55, No. 5, 2009, pp. 407-411. doi:10.3177/jnsv.55.407

[32] B. Gulson, K. Mizon, A. Taylor, M. Korsch, J. Stauber, J. M. Davis, H. Louie and M. A. L. Wu, "Longitudinal Monitoring of Selected Elements in Blood of Healthy Young Children," Journal of Trace Elements in Medicine and Biology, Vol. 22, No. 3, 2008, pp. 206-214. doi:10.1016/j.jtemb.2008.04.001

[33] J. L. Rodrigues, B. L. Batista, M. Fillion, C. J. S. Passos, D. Mergler and F. Barbosa, "Trace Element Levels in Whole Blood of Riparian Villagers of The Brazilian Amazon," Science of the Total Environment, Vol. 407, No. 13, 2009, pp. 4168-4173. doi:10.1016/j.scitotenv.2009.02.041

[34] M. L. Carvalho and A. F. Marques, "X-Ray Fluorescence Spectrometry: Applications in Trace Elements Studies in Human Tissues from Patients with Cirrhosis," X-Ray Spectrometry, Vol. 30, No. 6, 2001, pp. 397-402. doi: $10.1002 /$ xrs.517

[35] A. O. Ogunfowokan, J. P. Kaisam and M. O. Balogun, "Study of Trace Elements in Urine of Some Nigerian Medical Patients," Toxicological and Environmental Chemistry, Vol. 91, No. 3, 2009, pp. 435-449. doi: $10.1080 / 02772240802233597$
[36] Q. Pasha, S. A. Malik, J. Iqbal and M. H. Shah, "Characterization and Distribution of the Selected Metals in the Scalp Hair of Cancer Patients in Comparison with Normal Donors," Biological Trace Elemment Research, Vol. 118, No. 3, 2007, pp. 207-216. doi:10.1007/s12011-007-0035-7

[37] R. Pereria, R. Riberio and F. Goncalves, "Scalp Hair Analysis as a Tool in Assessing Human Exposure to Heavy Metals (S. Domingos Mine, Portugal)," Science of the Total Environment, Vol. 327, No. 1-3, 2004, pp. 81-92. doi:10.1016/j.scitotenv.2004.01.017

[38] M. Nadal, A. Bocio, M. Schuhmacher and J. L. Domingo, "Monitoring Metals in Population Living in the Vicinity of Hazardous Waste Incinerator: Levels in Hair of School Children," Biological Trace Elemment Research, Vol. 104, No. 3, 2005, pp. 203-214. doi:10.1385/BTER:104:3:203

[39] S. Majumdar, J. Chatterjee and K. Chaudhuri, "Ultrastructural and Trace Metal Studies on Radiographers' Hair and Nails," Biological Trace Element Research, Vol. 67, No. 2, 1997, pp. 127-138. doi:10.1007/BF02784068

[40] M. J. Welch, L. T. Sniegoski, C. C. Allgood and M. Habram, "Hair Analysis for Drugs of Abuse: Evaluation of Analytical Methods, Environmental Issues, and Development of Reference Materials," Journal of Analytical Toxicology, Vol. 17, No. 7, 1993, pp. 389-398. doi:10.1093/jat/17.7.389

[41] M. Balikova, "Hair Analysis for Drugs of Abuse: Plausibility of Interpretation," Biomed Pap Med Fac Univ Palacky Olomouc Czech Republic, Vol. 149, No. 2, 2005, pp. 199-207. doi:10.5507/bp.2005.026

[42] H. I. Afridi, T. G. Kazi, N. Kazi, G. A. Kandhro, J. A. Baig, M. K. Jamali, M. B. Arain and A. Q. Shah, "Interactions between Cadmium and Zinc in the Biological Samples of Pakistani Smokers and Nonsmokers Cardiovascular Disease Patients," Biological Trace Elemment Research, Vol. 139, No. 3, 2011, pp. 257-268.

[43] F. L. Barbieri, A. Cournil, J. E. S. Sarkis, E. Bénéfice and J. Gardon, "Hair Trace Elements Concentration to Describe Polymetallic Mining Waste Exposure in Bolivian Altiplano," Biological Trace Elemment Research, Vol. 139, No. 1, 2011, pp. 10-23. doi:10.1007/s12011-010-8641-1

[44] E. Rębacz, I. Baranowska-Bosiacka and D. Chlubek, "The Content of Selected Chemical Elements in the Hair of Young Men of the Bantu Language Group from Tanzania versus Environmental and Social Conditioning,' Biological Trace Element Research, Vol. 137, No. 3, 2010, pp. 262-279. doi:10.1007/s12011-009-8589-1

[45] V. L. Dressler, D. Pozebonb, M. F. Meskoc, A. Matuschd, U. Kumtabtime, B. Wue and J. S. Beckere, "Biomonitoring of Essential and Toxic Metals in Single Hair Using On-line Solution-Based Calibration in Laser Ablation Inductively Coupled Plasma Mass Spectrometry," Talanta, Vol. 82, No. 5, 2010, pp. 1770-1777. doi:10.1016/j.talanta.2010.07.065

[46] I. A. Olusegun and N. S. Gerhard, "Lead Exposure: A Contributing Cause of the Current Breast Cancer Epidemic in Nigerian Women," Biological Trace Elemment Research, Vol. 136, No. 2, 2010, pp. 127-139. 
doi:10.1007/s12011-010-8608-2

[47] S. Zaichick and V. Zaichick, "The Effect of Age and Gender on 37 Chemical Element Contents in scalp Hair of Healthy Humans," Biological Trace Elemment Research, Vol. 134, No. 1, 2010, pp. 41-54. doi:10.1007/s12011-009-8456-0

[48] G. R. Lloyd, S. Ahmad, M. Wasimc and R. G. Brereton, "Pattern Recognition of Inductively Coupled Plasma Atomic Emission Spectroscopy of Human Scalp Hair for Discriminating between Healthy and Hepatitis C Patients," Analytica Chimica Acta, Vol. 649, No. 1, 2009, pp. 33-42. doi:10.1016/j.aca.2009.07.005

[49] T. Wang, J. Fu, Y. Wang, C. Liao, Y. Tao and G. Jiang, "Use of Scalp Hair as Indicator of Human Exposure to Heavy Metals in an Electronic Waste Recycling Area," Environmental Pollution, Vol. 157, No. 8-9, 2009, pp. 2445-2451. doi:10.1016/j.envpol.2009.03.010

[50] A. Unkiewicz-Winiarczyk, A. Bagniuk, K. GromyszKałkowska and E. Szubartowska, "Calcium, Magnesium, Iron, Zinc and Copper Concentration in the Hair of Tobacco Smokers," Biological Trace Elemment Research, Vol. 128, No. 2, 2009, pp. 152-160. doi:10.1007/s12011-008-8266-9

[51] T. Chao, C. Hui and X. Chengyun, "The Prediction of Cardiovascular Disease Based on Trace Element Contents in Hair and A Classifier of Boosting Decision Stumps," Biological Trace Elemment Research, Vol. 129, No. 1-3, 2009, pp. 9-19. doi:10.1007/s12011-008-8279-4

[52] N. K. Mohammed and N. M. Spyrou, "Determination of Trace Elements in Hair from Tanzanian Children: Effect of Dietary Factors," Journal of Radioanalytical and Nuclear Chemistry, Vol. 278, No. 2, 2008, pp. 455-458. doi:10.1007/s10967-008-0903-4

[53] A. Rahman, M. A. K. Azad, I. Hossain, M. M. A. S. Qusar, W. Bari, F. Begum, S. M. I. Huq and A. Hasnat, "Zinc, Manganese, Calcium, Copper, and Cadmium Level in Scalp Hair Samples of Schizophrenic Patients," Biological Trace Elemment Research, Vol. 127, No. 2, 2009, pp. 102-108. doi:10.1007/s12011-008-8230-8

[54] J. L. Rodrigues, B. L. Batista, J. A. Nunes, C. J. S. Passos and F. Barbosa Jr., "Evaluation of the Use of Human Hair for Biomonitoring the Deficiency of Essential and Exposure to Toxic Elements," Science of the Total Environment, Vol. 405, No. 1-3, 2008, pp. 370-376. doi:10.1016/j.scitotenv.2008.06.002

[55] M. J. González-Muñoz, A. Peña and I. Meseguer, "Monitoring Heavy Metal Contents in Food and Hair in a Sample of Young Spanish Subject," Food Chemistry and Toxicology, Vol. 46, No. 9, 2008, pp. 3048-3052. doi:10.1016/j.fct.2008.06.004

[56] Y. Li, L. Yang, W. Wang, H. Li, J. Lv and X. Zou, "Trace Element Concentrations in Hair of Healthy Chinese Centenarians," Science of the Total Environment, Vol. 409, No. 8, 2011, pp.1385-1390. doi:10.1016/j.scitotenv.2011.01.017

[57] U.S. Census Bureau, 2010. http://www.census.gov/

[58] Y. Toba, R. Masuyam, K. Katot, Y. Takadal, S. Aoet, K. Suzuki, Y. Toba, R. Masuyama, K. Katot and Y. Taka- dal, "Effects of Dietary Magnesium Level on Calcium Absorption in Growing Male Rats," Nutrition Research, Vol. 19, No. 5, 1999, pp. 783-793.

[59] K. Kisters, F. Wessels, H. Kuper, F. Tokmak, E. Krefting, B. Gremmler, M. Kosch, M. Barenbrock and M. Hausberg, "Increased Calcium and Decreased Magnesium Concentrations and an Increased Calcium/Magnesium Ratio in Spontaneously Hypertensive Rats versus WistarKyoto Rats: Relation to Arteriosclerosis," American Journal of Hypertension, Vol. 17, No. 1, 2004, pp. 59-62. doi:10.1016/j.amjhyper.2003.08.012

[60] M. Kosch, M. Hausberg, G. Westermann, J. Koneke, F. Matzkies, K. H. Rahn and K. Kisters, "Alterations in Calcium and Magnesium Content of Red Cell Membranes in Patients with Primary Hypertension," American Journal of Hypertension, Vol. 14, No. 3, 2001, pp. 254-258. doi:10.1016/S0895-7061(00)01271-1

[61] A. Haenni, L. B. R. RetIeland, P. Anderssson, L. Lind and H. Lithell, "The Alterations In Insulin Sensitivity Angiotensin Converting Enzyme in Ii During Inhibitor Treatment are Related to Changes in The Calcium/Magnesium Balance," American Journal of Hypertension, Vol. 10, No. 2, 1997, pp. 145-151. doi:10.1016/S0895-7061(96)00343-3

[62] P. W. F. Fischer, A. Giroux and M. R. L'Abbk, "Effect of Zinc Supplementation on Copper Statusin Adult Man," The American Journal of Clinical Nutrition, Vol. 40, No. 4, 1984, pp. 743-746.

[63] W. P. Patterson, M. Winkelmann and M. C. Perry, "Zincinduced Copper Deficiency: Megamineral Sideroblastic Anemia," Annals of Internal Medicine, Vol. 103, No. 3 , 1985, pp. 385-386. doi:10.7326/0003-4819-103-3-385

[64] K. G. Porter, D. McMaster, M. E. Elmes and A. H. Love, "Anaemia and Low Serum-Copper during Zinc Therapy," Lancet, Vol. 2, No. 8041, 1977, p. 774. doi:10.1016/S0140-6736(77)90295-1

[65] R. K. Chandra, "Excessive Intake of Zinc Impairs Immune Responses," Journal of American Medical Association, Vol. 252, No. 11, 1984, pp. 1443-1446. doi:10.1001/jama.1984.03350110043027

[66] C. Fabris, R. Farini, G. D. Favero, G. Gurrieri, A. Piccoli, G. C. Sturniolo, A. Panucci and R. Naccarato, "Copper, Zinc and Copper/Zinc Ratio in Chronic Pancreatitis and Pancreatic Cancer," Clinical Biochemistry, Vol. 18, No. 16,1985 , pp. 373-375. doi:10.1016/S0009-9120(85)80078-3

[67] K. R. Beebe, R. J. Pell and M. B. Seasholtz, "Chemometrics-A Practical Guide," Wiley-Interscience, New York, 1998.

[68] K. W. Busch, I. M. Swamidoss, S. O. Fakayode and M. A. Busch, "Determination of the Enantiomeric Composition of Guest Molecules by Chemometric Analysis of the UVVisible Spectra of Cyclodextrin Guest-Host Complexes," Journal of the American Chemical Society, Vol. 125, No. 7, 2003, pp. 1690-1691. doi:10.1021/ja025947a

[69] M. Otto, "Chemometrics," Wiley-VCH: Weinheim, Weinheim, 1999.

[70] E. Marengo and M. Aceto, "Statistical Investigation of the Differences in the Distribution of Metals in Nebbiolo- 
based Wines," Food Chemistry, Vol. 81, No. 4, 2003, pp. 621-630. doi:10.1016/S0308-8146(02)00564-2

[71] C. Diaz, J. E. Conde, D. Estevez, S. J. Perez Olivero and J. P. Perez Trujillo, "Application of Multivariate Analysis and Artificial Neural Networks for the Differentiation of
Red Wines from the Canary Islands According to the Island of Origin," Journal of Agricultural and Food Chemistry, Vol. 51, No. 15, 2003, pp. 4303-4307. doi:10.1021/jf0343581 